Trikonomika

Volume 19, No. 1, June 2020, Page. 8-15

ISSN 1411-514X (print) / ISSN 2355-7737 (online)

\title{
GLOBALIZATION AND ITS IMPACT ON ECONOMIC GROWTH: EVIDENCE FROM ASEAN COUNTRIES
}

\author{
Martini \\ martinidhasman087@gmail.com \\ STIE Musi Rawas \\ J1. Trans Sumatera Lahat - Lubuk Linggau, Sumatera Selatan 31626
}

received: 20/2/19; revised: 26/4/19; approved: 29/6/20

\begin{abstract}
This study investigates the impact of globalization toward economic growth in ASEAN countries during 2012 to 2017. The research method used judgmental sampling with samples of 11 countries. They were Brunei Darussalam, Cambodia, East Timor, Indonesia, Lao PDR, Malaysia, Myanmar, Philippines, Singapore, Thailand, and Vietnam. The analysis used path analysis to examine the impact between the variables of globalization and economic growth. Globalization was determined by globalization index, economic globalization, social globalization, and politie globalization Rea Gross Domestic Product (GDP) and Gross Domestic Product (GDP) percapita are used as a prox
for economic growth. The finding results are that globalization index, economic globalization social globalization, and politic globalization have a significant positive asso Domestic Product (GDP) and Gross Domestic Product (GDP) evidence the positive impact on economic growth in ASEANC Ountries

Keywords: globalization; economic growth; (People's Democratic Republic), Malaysia, Myanmai,
(Perusalam, Cambodia, East Timor, Indonesia, Lao PDR Philippines, Singapore, Thailand, and Vietnam. The establishment of this regional organization aims to increase multilatera cooperation between countries in the Southeast Asian region. This form of cooperation between countries ineludes the economic, social and cultural fields, as well as the defense of the security and peace of ASEAN countries (Ying et al. 2014: 33).

Economic development in Southeast Asia is one of the main concerns. This development coupled with the existence of globalization that continues to run and spread in various parts of the world makes economic mobility in the Southeast Asian country increasingly rapid. Global developments experienced by countries in Southeast Asia make this region need to conduct economic cooperation in the international world, given the importance of trade with other countries both in Southeast Asia and outside of Southeast Asia. Economic cooperation is one of the opportunities that businesses can use in Southeast Asia to compete internationally. In addition, the Southeast Asia region must be an attractive market for foreign investment.
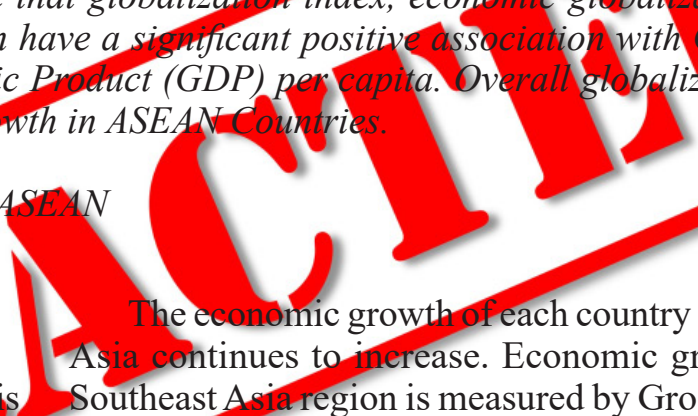
Southeast Asia region is measured by Gross Domestic Produet (GDP). The following is a comparison of Gross Domestic Product (GDP) growth in the previous year until the last of 2017, indicating that Gross Domestic Product (GDP) countries in Southeast Asia continue to experience a better change.

Figure 1 explains that only Indonesia experienced a decline in the annual growth rate of $0.21 \%$ from the previous year. This is a significant decline given that other countries in the Southeast Asian region continue to experience an increase. It was concluded that almost all countries in the Southeast Asian region experienced an increase in Gross Domestic Product (GDP) to be better. Gross Domestic Product (GDP) is an indicator of measuring a country's economic growth. According to the annual Gross Domestic Product (GDP) growth rate data, this illustrates that economic growth in Southeast Asia continues to grow. Hamdi (2013: 143) explained that economic growth is influenced by several factors, one of which is globalization.

Hamdi (2013: 143) also explained that the process of globalization has involved all countries around the world. Developing countries in India, China, Africa, Iraq, Syria, Lebanon, and Jordan have been influenced by globalization, whether negatively or positively, the
\end{abstract}

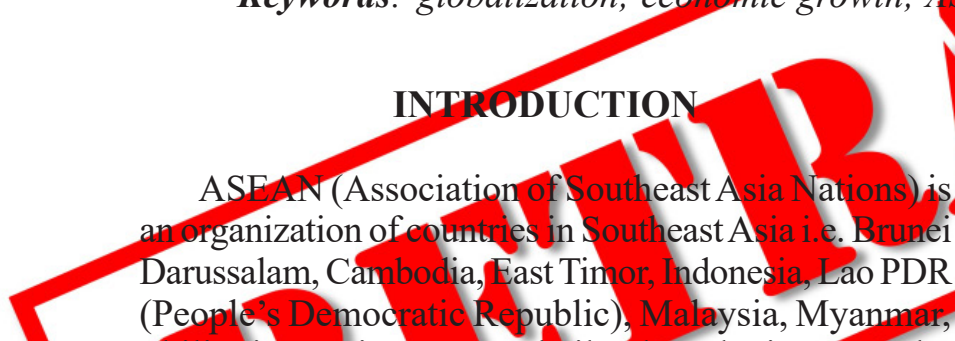


economies of these countries have improved under the influence of globalization. Globalization is progress and ease in the form of products, services, labor, and capital. Globalization brings the freedom of developed countries to be able to establish cooperation in terms of trade to increase economic growth. Globalization is a phenomenon that cannot be avoided. Globalization is not only related to the economic field, but also in the political, social and international relations environment (Wolf, 2004).

Globalization in a country was able to see in the interdependence between countries increasing the integration of trade, population, and ideas within a global market. The process of globalization is also influenced by various factors, namely economic, natural resources, market, politics, and technology. Several studies have also been carried out regarding globalization and its effects on economic growth, as Dreher (2006) explained that globalization has a positive impact on economic growth. This research was also supported by Samimi and Jenatabadi (2014) who added that not only from the economic side, globalization had an impact on the political and social systems. However, globalization also does not all have positive impacts, research conducted by Ying et al. (2014), explaining that globalization does have a positive influence on economic growth, but ha a negative impact on social and political interests in the ASEAN countries (Association of Southeast Asia Nations). The negative impact is in the form of inequality between countries that are inereasingly large, research conducted by Suci et al. (2015) and Ying et al. (2014). The relationship between globalization and economic growth is not a recent topic to debate. Theoretically, the study of globalization and economic growth is still co a positive influence from globalization on economie
growth through the effectiveness of the allocation of
domesticresources, techmology diffusion, increased productivity and capital. Conversely, other studies say that globalization has a negative effect on economic growtl, especially in countries with weak and unstable political conditions (Borensztein et al. 1998: 115).

Research on globalization and economic growth is still going on until now. Even research in developing countries has been done a lot before. Research in the Southeast Asian region related to globalization and economic growth has been widely carried out. Research conducted by Ying et al. (2014) explained that economic globalization proved to be more effective than political or social globalization in promoting economic growth. The government has to be more active in promoting international trade and foreign investment, while striving to increase participation in economic organizations and adopt outside-oriented policies, encouraging interaction with other countries. The government has to pay close attention to the negative impact on social and political globalization on economic growth.
This research is a replication of previous research that has been done (Dreher, 2006; Samimi and Jenatabadi, 2014) concerning globalization and influence on economic growth in southeast Asia. The analysis uses SmartPLS to see the most relevant and significant indicators of globalization and economic growth. This study analyzes the influence of globalization which is seen from four indicators. They are globalization index, economic Globalization, social globalization, and political globalization. Economic growth evolves out two indicators, they are real Gross Domestic Product (GDP) and Gross Gross Domestic (GDP) per capita in Asian countries Southeast. This research is important to analyze how far a country can be involved in the process of globalization. Specifically, the path of globalization has a good and bad impact on economic growth. This information is able to give consideration to the government to regulate the level of openness of the country towards each of these paths of grobalization so as to minimize the adverse effects of globalization on economic growth in each country in Southeast Asia.

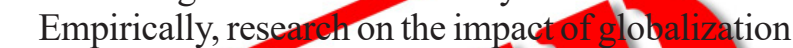
on economic growt has been widely carried out. This research replication of previous research that has concerning globalization and growth in Southeast Asia. Dre effects on eeonomic comprehensive new globalization index, that was KOF. KOF examined the impact of globalization on growth in dynamic panels that was uneven in 123 countries between 1970 and 2000 The overall results show that social dimensions have a positive impact on economic growth while the political dimension does not affect onomic growth.

The results of this study were supported by Rao and Vadlamannati (2011) who used KOF in examining the impact of globalization on the rate of economic growth in 21 countries in Africa during 1970-2005. The result is globalization has a positive effect on economic growth and the positive influence of globalization on economic growth is greater than the influence of investment on economic growth. Ying et al. (2014) investigate the influence of individuals and groups on the three constructs of globalization on real Gross Domestic Product (GDP). The results show that in ten ASEAN member countries, economic globalization has a positive influence on economic growth, while social and political globalization has a negative effect.

Samimi and Jenatabadi (2014) conclude that the positive effects of globalization are increasing in countries with higher educated workers and a well-developed financial system. Our findings indicate that the influence of economic globalization also depends on the level of state income. High and middle-income countries have an advantage from globalization, while low-income countries have a disadvantage of globalization. In fact, 
countries have to receive an appropriate level of income to benefit from globalization. Economic globalization does not directly promote growth but also indirectly does so through complementary reforms.

Moreover, another study conducted by Maduka et al (2017) also explains that globalization has broadened the influence of the country's economic growth and development. This proves the world competition and influence that has succeeded in driving progress in the world. Kakar (2011) also said a similar way, that globalization has provided positive benefits to economic development in a country, including Pakistan. Globalization has reduced income in the country. However, Kihcarslan and Yasemin (2018) propose different things, that social globalization and economic globalization have increased economic growth, while political globalization has no significant impact on economic growth. Majidi (2017) also contributed to his research which explained the index of globalization and political globalization which played a role in economic growth in developing countries related to the middle to lower income levels. While the factors of social globalization and economic globalization have a significant influence.

Concluded from the research conducted, it still shows the variation between globalization and economic growth. While the average on a positive relationship (Ying et al., 2014; Dreher, 2006; Samimi and Jenarabadi, 2014; Rao and Vadlamannati, 2011; Kakar, 2011; and Maduka, 2017). However, several other studies also expressed negative impact (Dreher, 2006; Kihcarslan and Yasemin, 2018. Majidi, 2017). The existence of these differences provides an overview of globalization that has provided changes in a country, most developing well as countries that have a negative influence from globalization that is happening right now.
Based on the research conducted, globalization
has a significant impact on economic growth because
it is able to provide more economie value to a country. it is able to provide nore economie value to a country. Globa ization is not only seen as a whole but also seen from several important factors, like economic, social and political. Globatization based on these three factors has different impact on a country's economic growth. The pesitive impact of globalization is the increasing state revenue. The higher the percentage of economic growth illustrates that the country is financially healthy, also the level of welfare of the population is getting better.

Economic growth is a process where there is an increase in real gross national product or real national income. So the economy is showed to grow or develop if there is real output growth. Gross Domestic Products (GDP) value is used in measuring the percentage of a country's economic growth. Gross Domestic Products (GDP) is an indicator in determining economic growth in this study, like Gross real Domestic Products (GDP) and Gross Domestic Products (GDP) per capita. The process of globalization and increasing economic growth have involved all countries around the world. Including Southeast Asia. Globalization provides many opportunities for developing countries to increase trade and broader economic achievements in terms of international business. Based on this explanation, a hypothesis is globalization has a positive effect on economic growth in ASEAN countries.

\section{METHODS}

This research was conducted using globalization index data published by the KOF index of globalization in the Swiss Economic Institute. The KOF Globalization Index (KOFGI) sees globalization from an economic, social and political perspective. Data for economic growth variables comes from the World Bank database. Economic growth is measured by Gross real Domestic Products (GDP) and Gross Domestic Products (GDP) per capita. The sample of this study were 1 countries in ASEAN (Association Southeast Asian Nations) members. they are Brunei Darussalam, Cambodia, East Timor, Indonesia, cao PDR, Malaysia Myanmar, Philippines, Singapore, Thailand, and Vietnam. This study use annual data over a period of 6 years, start to see the impact of globalization on edonomie growth with each indicator.

Research model of globalization to economic wth is depicted wit

Figure 2 illustrates that researeh uses 2 variables, namely globalization as exogenous variables with 4 indicators, namely globalization index, economic globalization, social globalization, and political globalization. The second variable is economic growth as an endogenous variable. Economic growth variables have two indicators, namely the Gross Domestic Product (GDP) and Gross Domestic Product (GDP) per capita. This research is able to detect directly on each of the indicators studied, through the variables that are connected.

Model research formulation:

Economic growth $=\alpha+\beta$ globalization $+\mathrm{e}$.

Evaluation of Measurement Model (Inner Model) has used a). Composite Reliability ( $\rho c)$, is used to measure the consistency of the indicator block. It is recommended that the value of Composite Reliability $(\rho c)$ is greater than 0.5 (Ghozali and Hengky, 2015: 76). And b). Convergent Validity is seen based on the correlation between item/indicator scores and construct scores. Individual reflective size is said to be high if it correlates more than 0.7 with the construct to be measured (Ghozali and Hengky, 2015: 76).

Testing The PLS hypothesis does not assume that data is normally distributed, instead PLS relies on non-parametric bootstrap procedures to test the 
significance of the coefficients (Hair, et al., 2014: 44). The test measures the $\mathrm{t}$-count value and the standard error obtained from bootstrapping. When the size of the empirical value of it is produced $>1.96$. It is assumed that the path coefficient is significantly different from the $5 \%$ significance level $(\alpha=0.052$-way test).

Table 1 informs that globalization is a process of change as a whole and wide world. This change is limitless for anything. This study looks at globalization in countries in southeast Asia with a sample of 11 countries. They are Brunei, Cambodia, East Timor, Indonesia, Lao PDR, Malaysia, Myanmar, Philippines, Singapore, Thailand, and Vietnam. the sample is all the population used in the study.

Globalization has many impacts on economic, social and politic. The changes to globalization as a whole are held by Singapore as a country with the highest average index globalization of $87 \%$ followed by Malaysia and Thailand, it is $79 \%$ and $68 \%$. This proves that as a whole, a country that experiences many impacts on the entry of globalization is Singapore. The country that has experienced a bit of globalization is Lao PDR which is $29 \%$, followed by Myanmar by $34 \%$ and East Timor 35\%.

Economic globalization is a change in terms of a country's economy. these changes include increasing economic integration and economic interdepentence nationally, regionally and locally throughout the world. Changes that occur in terms of cross-border movement of goods, services, technology, and capital. The highest economic globalization also occurred in Singapore at $97 \%$. Then, Malaysia as the second rank of 79 and third is Thailan $70 \%$. These three countries are economically aetive countries int he era of globalization, especially
Singapore as one of the countries with the bestfinancial system in the world. Countries experiencing relatively system economic changes in the globalization era are
Lao PDR of $9 \%$. ctevity also has an impact on the emergence of globalization. Changes in globalization make people think more rationally and structurally. More accepting cultural values outside and open in terms of information and knowledge. Social Globalization (SG) in Southeast Asia illustrates that Singapore is a country with many social changes for the impact of globalization. Singapore has the highest percentage of 91\% compared to other countries in Southeast Asia. Second is Malaysia with $74 \%$. However, Myanmar and East Timor have a small social change presentation of the globalization that has taken place, they are $16 \%$ and $21 \%$. Based on this value, it proves that Myanmar and East Timor still maintain an indigenous culture and without any change in attitudes in their country's social environment.

Globalization also brings political change in a country. Political globalization is the process of entering a pattern or values that are accepted as a whole because it brings renewal and benefits in the political field, it is like political cooperation between countries by forming a multilateral international organization. Indonesia and Philippine are the countries with the highest politic globalization of $87 \%$ and $86 \%$. Next followed by Thailand at $81 \%$. they are countries that have the most impact of political globalization. Like changes to democratic, free, wise and open government and increased human rights enforcement. The country with the smallest change in political globalization is Myanmar $37 \%$, then East Timor and Lao PDR respectively 38\%. Based on the historical background, Myanmar and Lao PDR are communist countries, so they have little impact on the political activities of globalization.

Economic growth is a process of changing the economy in a country that is continuously going into a better state for a certain period. The intended economic changes are an increase in a country's produetion capacity and income. Indicators of economic growth in this study are real Gross Domestic Product (GDP) and Gross Domestic Product (GDP) per capita. The study used 11 countries in Southeast Asia. They are Brunei, Cambodra, East Timor, ndonesia, Lao PDR, Malaysia Myanmar, Philippines, Singapore, Thailand, and Vietnam.

The average Gross Domestic Product (GDP) can be used to compare the size of economies around the world. Real Gross Domestic Product (GDP) is a measurement of economic output that takes into aceount the impact finflation or deflation. It reports Gross Domestic Product (GDP) assuming that prices never rise or fall, which provides a more realistic growth assessment. Otherwise, it can seem like a country that produces more if only the price has risen. Indonesia has the highest economic growth in Southeast Asia at 933. Another countries, Thailand also have a high Gross Domestic Product (GDP) but its value is half that of Indonesia. This proves that Indonesia has very good economic performance compared to other countries in Southeast Asia. However, this situation is different from the East Timor country which has a Gross Domestic Product (GDP) of only 4, proving that the economy of the new country is not yet stable and good.

The average of Gross Domestic Product (GDP) per capita in Southeast Asia, and illustrates that Singapore is the country with the highest GDP per capita of 52,305 and Brunei Darussalam of 33,227. It is concluded that Singapore is the country with the best level of prosperity and development compared to other countries in Southeast Asia. Then Brunei Darussalam and Malaysia are about 33,227 and 10,564. However, Cambodia is the country with the lowest GDP per capita in Southeast Asia. Cambodia is worth 1,002, then Myanmar is about 1,298 and Lao PDR is about 1,513 (Table 2).

Real Gross Domestic Product (GDP) in Southeast Asia is still relatively small. This is also seen in the 
Gross Domestic Product (GDP) per capita. Southeast Asia is in the category of developing countries. This shows that GDP growth per capita is still in the middleincome stage. According to the World Bank (2012) divides per capita income into several groups, they are: (1) Low income $\leq 1,045$ US \$; (2) Lower - middle income 1,046 - 4,125 US \$; (3) Upper - middle income 4,126 - 12,745 US \$; (4) High income > 12,745 US \$.

According to the world bank, only Singapore and Brunei Darussalam are in the high-income category. While other countries in Thailand and Malaysia are in the upper-income category. The majority of countries in ASEAN are in lower-income to middle-income categories, they are Indonesia, East Timor, Philippines, Vietnam, Lao PDR, and Myanmar. Cambodia is categorized as a low-income country.

Table 3 shows that variables of Globalization use four indicators, they are globalization index, economic globalization, social globalization, and political globalization. The minimum value for each indicator is $0 \%$ and the maximum is $100 \%$. Observations show that economic globalization has the smallest indicator, which is $9 \%$. Economic globalization has the lowest value compared to other globalization indicators. While the highest value for indicators of globalization is $97 \%$ also derived from economic indicators of globalization This happens because the most important factor of globalization is the economy. Because the entry of globalization helps the country's economic sector a lot and has the most impact on the economy- of each country.

Overall average of $50 \%$ in southeast $A$ sia. It was concluded that the effects of globalization had changed th social and political systems in Southeast Asia.Politics
and economics included the most frequent changes,
$65 \%$, and $58 \%$. Globalization has provided many
changes in several sectors of the government and the
country's edonomy.
Variables of Economic growth use two indicators, they are real Gross Domestic Product (GDP) and Gross Domestic Product (GDP) per capita. Based on the observations, it shows that the real Gross Domestic Product (GDP) has the smallest indicator, which is 4 and the highest reaches 922. The average real Gross Domestic Product (GDP) 231.64 is a small measure of highest real Gross Domestic Product (GDP).

According to the outer loading value, it is explained that all variable indicators of economic growth and globalization have values above 0.5 and significant. Outer loading is used to see convergent validity with the correlation value must be above 0,5 . The outer loadings table, the variables used in the study have validity in correlating with the indicators used.

The construct of reliability test is measured by looking at composite reliability. Constructions are declared reliable if they are above 0,6 . The cut off for composite reliability is the same as any measure of reliability and score between 0.6 and 0.7 is a good indicator of construct reliability (Ghozali and Hengky, 2015: 77). All constructs are above 0,6 which indicates that globalization and eco growth are reliable and the indicator blocks in each construct have high consistency.

The model of globalization on economic growth is influenced by R-square value is about 0.631 . It is interpreted that the globalization construct variability is about $63 \%$ affects economic growth (Table 4 ).

The general model elements in the SmartPLS 3.0 output explained that the total latent variables in this study amounted to 2 variables, in which observed variables (manifest variables) were 6 indicators, 4 indicators for Globalization and 2 indicators for Economic growth. The evaluation between latent variables showed that the hypothesis test is measured by looking at the path coefficient between variables and then compare $p$-value with the alpha value $(0.05)$ i the output of SmartPLS 3,0. The analysis is explained in Figure 3 and Figure 4.

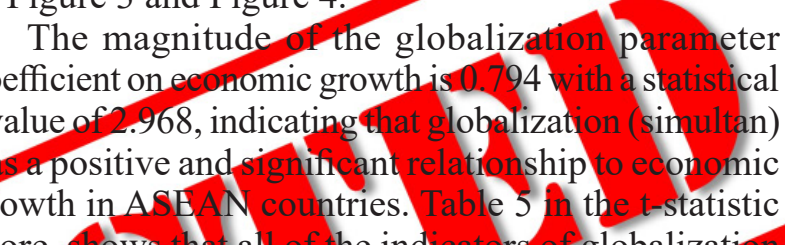
score, shows that all of the indicators of globalization are globalization index, economic globatization, cial globalization and politic globalization indices ositive globalization, and significant to GDP apita. However, the index of globalization, economic globalization, social globalization, and politic globalization does not affect real GDP. It was concluded that globalization Indicators have increased e GDP of per capita in the country, this proves that globalization has improved people's welfare in the ASEAN countries.

\section{DISCUSSION}

This study shows that globalization is able to increase economic growth, countries that experience globalization is going to feel the impact directly with the improvement of people's welfare. It was concluded that globalization in countries of ASEAN countries contributes a positive influencing on the country's economic growth. The economic aspects of globalization as measured by economic growth illustrates that economic globalization gives a good effect on economic growth. Globalization helps the market more open to export and import goods. Providing opportunities for Indonesian entrepreneurs to increasingly innovate to create quality local products that compete internationally. Economic globalization brings an atmosphere for entrepreneurs to access investment capital from abroad. Items needed by the community become easier to obtain. This global economic activity 
is certainly very beneficial for the country because raising national income ultimately makes economic growth in a country even higher.

In addition to the economy, other aspects that have also experienced change are social, social globalization making society as a whole more upholding the value of human rights. The existence of gender equality makes women's rights to freedom of opinion and expression so that women's emancipation can be enforced. In addition to these values, environmental conditions are also benefited from social globalization, namely increased tourism and entertainment activities. This makes government revenue increase. So that a country's economic situation can improve.

Another aspect is political globalization (PG) capable of increasing the country's economic growth. Seen in the policies taken by the government. Politics of globalization makes the government system open and democratic because the government is part of a country. If the government is run honestly, cleanly and dynamically, it will certainly get a positive response from the people. This positive response in the form of identity towards the country has increased and public trust will support what is done by the government. Good cooperation between the government and the people, making the economic flow also improve, well as implementing pro-people policies so that economic problems (poverty, social inequality) are reduced.

Overall, globalization helps ASEAN in achieving organizational goals (ASEAN, 2018):(1) To accelerate the economic growth, social progress and cultural development in the region through joint endeavors spirit of equality and partnership

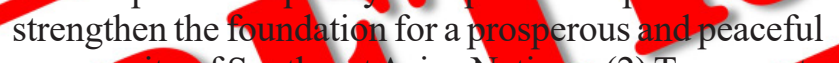
active collaboration and mutualassistance on matters of common interest in the economic, social, cultural, technical, scientificand administrative fields.

Globalization has helped programs by ASEAN in order to increase economic growth. According to the ASEAN objectives outlined, globalization helps accelerate economic growth, an increasingly advanced social situation and a shared cultural development in upholding equality and partnership for a superior, prosperous and peaceful Southeast Asian community.

Globalization has several indicators that can be measured, namely political, economic and social. The indicator depends on the economic structure of each country. some have a positive effect, some have a negative effect on economic growth. Based on previous research, shows that this research supports the research that has been done. Dreher (2006) states that globalization has driven economic growth. Economic and social globalization has a positive impact on economic growth, while political globalization has no effect on economic growth. Furthermore, Majidi (2017) also added that in developing countries, globalization as a whole had an effect on economic growth. Even so on political globalization. But economic and social globalization has no significant effect. Kihcarslan and Yasemin (2018) state a similar thing, that economic globalization and social globalization have increased the economic growth of Turkey. While social globalization does not affect the country's economic growth.

Ying et al. (2014) also concluded that economic globalization has a positive influence on economic growth, while social and political globalization has a negative effect. Economic globalization encourages economic growth while social and political globalization has a negative effect and does not benefit the country's economic growth. Samimi and Jenatabadi (2014) conclude that the effects of economic globalization affect the level of state income. High and middleincome countries benefit from globalization, while low-income countries do not benefit from it. In fact countries must receive an appropriate level of income to benefit from globalization Economic glebalization does not directly promote growth but also indirectly does so througteomplementary reforn
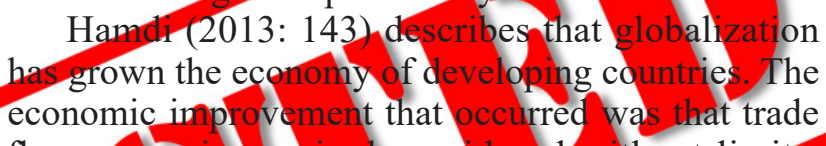
flows were increasingly rapid and without limits. Globalization has brought developing countries more enefits than losses. Certainly, the role of government is important in the process, such as more and the greatest oppontunities for people in both developed and developing countries to sell as many items as possible to many peoplenow, so we can say this is the golden age for business, commerce, and trade.

\section{CONCLUSION}

This study attempts to analyze the impact of globalization on economic growth in ASEAN countries during 2012 to 2017. Research evidence globalization has a positive effect on economic growth. Globalization index, Economic globalization, social globalization, and politic globalization have a positive relationship to Gross Domestic Product (GDP) and Gross Domestic Product (GDP) per capita. It was concluded that the findings of this study support the findings of previous studies conducted by Dreher (2006), Ying (2014), Samimi and Jenatabadi (2014) that globalization directly affects economic growth in a country. Globalization that has occurred has a positive impact on the development of the welfare of the population. globalization helps improve the ASEAN countries' programs in the economic prosperity of their countries, thus making people's lives better.

The study was conducted using secondary data for variables of globalization and economic growth. The study only uses data for the past 6 years, they are 
2012-2017. Subsequent research can use more years of data up to the last 10 years or more. Research variables are also more developed with a variety of variables, in addition to the indicators in the research of Dreher (2006), Ying (2014), Samimi and Jenatabadi (2014) and Kihcarslan and Yasemin (2018) are like population equity, poverty level, and other relevant variables.

\section{REFERENCES}

Borensztein, E., J. De Gregorio, and Lee, J-W. 1998. How Does Foreign Direct Investment Affect Economic Growth?. Journal of International Economics 45: 115-135.

Dreher, A. 2006. Does Globalization Affect Growth? Evidence from a New Index of Globalization. Applied Economics 38(10): 1091-1110. DOI: 10.1080/00036840500392078.

Ghozali, Imam and Hengky Latan. 2015. Partial Least Squares concepts, techniques, and applications Using SmartPLS 3.0 Program. Semarang: Diponegoro University Publishing Agency p. 76-77.

Hair, Joseph E, Jr. et al. 2014. A Primar Of Partial Least Squares Structural Equation Modeling (PLSSEM). Sage Productions, Inc. California. USA p. 44. Accessed August 2018

Hamdi, Fairooz Mustafa. 2013. The Impaet of Globalization in the Developing Countries. ISSN 2224-607x (Paper). ISSN 2225-0565 (Online). Www.Iiste.Org 3 (11) : 142-144. AccessedAugust 2018.

Kakar, Zaheen Khan., Bashin Ahmad Khilji, and Muhammad Jawad Khan 2011. Globalization and Economic Growth: Evidence from Pakistan. Acta Universitatis Danubius (AUD) Vol 7 (3) 208-217.

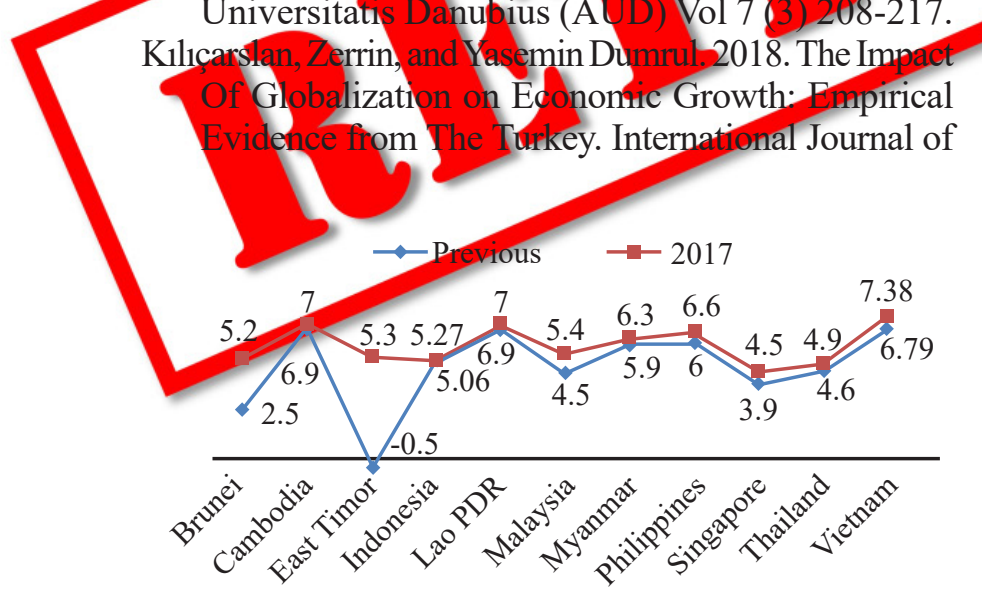

Source: World Bank, 2018

Figure 1. Annual GDP Growth Rate in Previous Year and 2017
Economics and Financial, Vol 8(5), 115-123.

Kof Index of Globalization. The Swiss Economic Institute. Http://Globalization.Kof.Ethz.Ch/. Accessed on September 2018.

Maduka, A. C., Madichie, C. V. , And Eze, E. A2. 2017. Globalization and Economic Growth: Evidence from Nigeria. International Journal of Social Science and Economic Research ISSN: 2455-8834 Vol 02 (8) 4177-4191.

Majidi, Ali Fagheh. 2017. Globalization and Economic Growth: The Case Study of Developing Countries. Asian Economic and Financial Review. Vol 7(6) 589599. Doi: 10.18488/Journal.Aefr.2017.76.589.599

Rao, Bb., and Vadlamannati, K.C. 2011. Globalization and Growth in the Low-Income African Countries with the Extreme Bounds Analysis. Economic Modelling 28: 795-805. DOI: 10.1016/j. econmod.2010.10.009.

Samimi P and Jenatabadi H. 2014. Globalization an Economic Growth: Empirical Eridence on the Role of Complementarities. Ww.Plosone Org 9 (4): 1-7. DOI:10.1371 Journal.Pone.0087824

Suci, S.C., Asmara, A. and Mulatsih, S, 2015. The impact of gtobalization on economic growth in ASEAN Bisnis \& Birokrasi Journal, 22(2), pp.7

The World Bank, Available at http:/www worldbank. org/unite nations/. Accessed September 2018 e Association of Southeast Asian Nations (ASEAN), Available at https//asean.org/asean/about-asean/ overview/. Accessed September 2018.

Martin.2004. Globalization And Interdependence. Haven Yale University. Available at: http://www.un.org/esa/documents/un.oct.2004. globalisation.and.interdepence.pdf. Accessed on September 2018.

Ying, Y.H., Chang, K. and Lee, C.H., 2014. The impact of globalization on economic growth. Romanian Journal of Economic Forecasting, 17(2), pp.25-34.

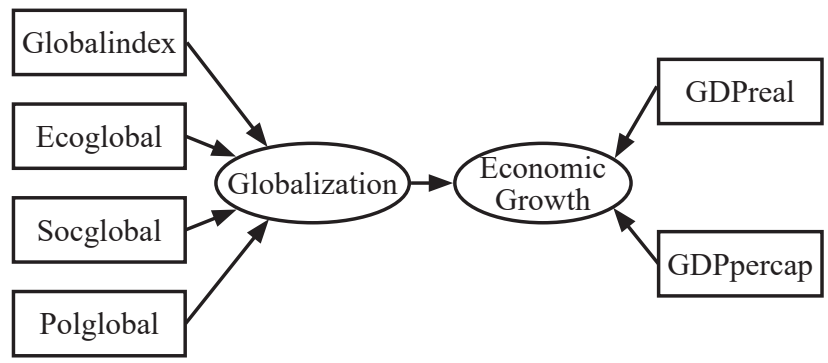

(Source: Author, 2018)

Figure 2. Research Model 


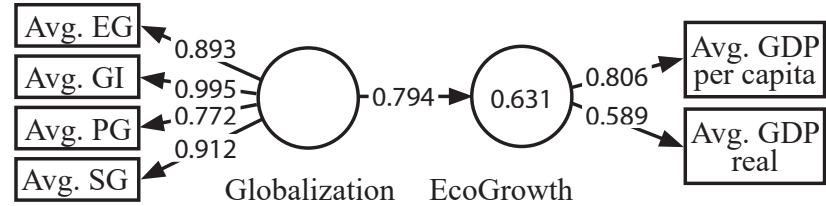

Source: Author, 2018.

Figure 3. Outer model

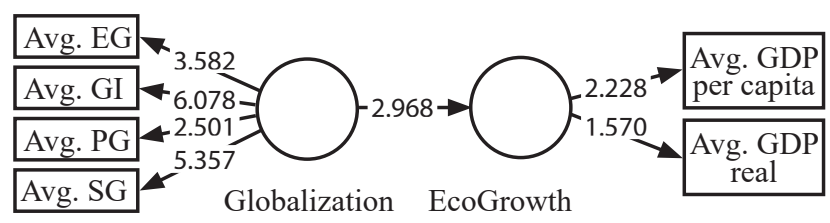

Source: Author, 2018.

Figure 4. Outer loading

Table 1. The Comparison of Globalization in ASEAN

\begin{tabular}{lllll}
\hline \multirow{3}{*}{ No } & Country & \multicolumn{4}{c}{ Globalization } \\
\cline { 2 - 5 } & Average & Average & Average & Average \\
& IG & EG & SG & PG \\
\hline
\end{tabular}

Table 2. The Comparison of economic growth in ASEAN

\begin{tabular}{llcc}
\hline & & \multicolumn{2}{c}{ Economic growth (Billion USD) } \\
\cline { 3 - 4 } No & Countries & $\begin{array}{c}\text { Average of real } \\
\text { GDP }\end{array}$ & $\begin{array}{c}\text { Average of GDP } \\
\text { per capita }\end{array}$ \\
\hline 1 & Brunei Darussalam & 15 & 33.227 \\
2 & Cambodia & 18 & 1.002 \\
3 & East Timor & 4 & 3.130 \\
4 & Indonesia & 922 & 3.767 \\
5 & Lao PDR & 14 & 1.513 \\
6 & Malaysia & 314 & 10.564 \\
7 & Myanmar & 63 & 1.298
\end{tabular}

8 Philippines $\quad 286 \quad 2.574$

9 Singapore $\quad 307 \quad 52.305$

$\begin{array}{llll}10 & \text { Thailand } & 5.727\end{array}$

11 Vietnam $\quad 189 \quad 1.619$

Source: World Bank, 2018

Table 4. Overvi

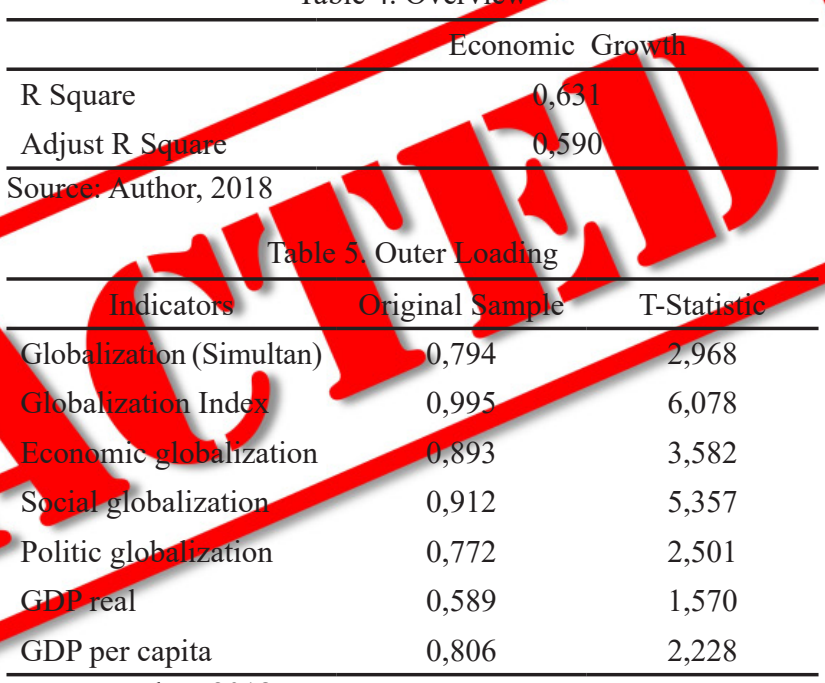

Source: Author, 2018

Table 3. Result Results of Descriptive Variable Statistical Analysis

\begin{tabular}{llccccc}
\hline & \multicolumn{2}{c}{ Theoretical } & \multicolumn{3}{c}{ Actual } \\
\cline { 2 - 6 } Variables & Min-Max & Mean & Min-Max & Mean & Std. Deviation \\
\hline Globalization & & & & & \\
\hline 1. Globalization Index & $0-100$ & 50 & $29-87$ & 55,36 & 18,533 \\
2. Economic Globalization & $0-100$ & 50 & $9-97$ & 57,91 & 22,358 \\
3. Social Globalization & $0-100$ & 50 & $16-91$ & 43,36 & 24,594 \\
4. Politic Globalization & $0-100$ & 50 & $37-87$ & 63,18 & 19,879 \\
\hline Total & $0-400$ & 50 & $91-362$ & 54,95 & 21,34 \\
\hline 1. Real GDP & $0-\infty$ & $\infty$ & $4-922$ & 231,64 & 237,50 \\
2. GDP per capita & $0-\infty$ & $\infty$ & $1.002-52.305$ & $10.611,45$ & $16.684,79$ \\
\hline Source
\end{tabular}

Source: Author, 2018 